\title{
Weapon lab security may hit foreign visits
}

[WASHINGTON] Security is being tightened at the US Department of Energy's major weapons laboratories in the wake of the dismissal of a Los Alamos National Laboratory engineer for alleged involvement in a securitybreach.

But scientists are worried that the political reaction to the leak, which may have occurred more than a decade ago, will reduce or end contacts between the laboratories and foreign scientists (see Nature 398, 96; 1999).

Wen Ho Lee was fired from Los Alamos not for espionage, which remains unproven, but for talking to Chinese scientists and failing adequately to report the conversations. Lee, a 20 -year veteran at Los Alamos, had been working under contract for the laboratory. The energy department believes he may have aided Chinese visitors in gathering information on the $\mathrm{H}-88$ missile warhead.

The incident at Los Alamos has touched off a political storm in Washington. Republicans in Congress are eager to use the issue to score political points against President Bill

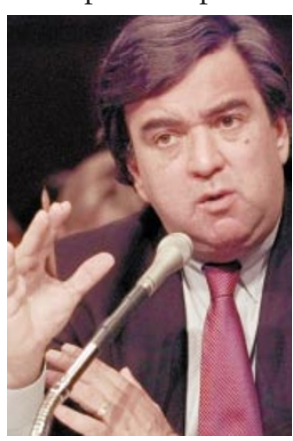

Clinton and VicePresident Al Gore, who will be running to succeed Clinton in the 2000 election.

John Pike, a defence analyst at the Federation of American Scientists in Washington, says: "They are making this sound like Los Alamos is a

Richardson: keen to protect visiting scientists programme. [convenience store] with H-bombs ready to go. The real question is whether Lee walked out the front door with the H-88 warhead under his arm or whether he ran off a little at the mouth in conversation over dinner."

The General Accounting Office has already published several studies criticizing security procedures at the three weapons laboratories, Los Alamos and Sandia in New Mexico and Lawrence Livermore in California.

John Browne, the director of Los Alamos, insists that the security breach was real and the firing was deserved. Lee was not fired for theft of nuclear secrets, says Browne. "He lost his job for security violations, not for espionage."

Last Friday (19 March) a delegation from Washington visited Los Alamos to review the new security procedures. They included Ernest Moniz, the energy under-secretary, Vic Reis, the assistant secretary with responsibility for nuclear weapons, and Ed Curran, head of the energy department's Office of Counterintelligence.
The initiatives include an additional $\$ 8$ million on the department's 2000 budget request to start a 'cyber-information' security programme. The amount would raise the department's proposed counter-intelligence budget to $\$ 39.2$ million.

Other steps include measures to control weapon design data in secret documents at the laboratories; the appointment of former Central Intelligence Agency director John Deutch to review the energy department's foreign visitors and assignments programme; and a review of how the department maintains its counter-intelligence files.

Extra 'counter-intelligence professionals' have been appointed to the laboratories, and procedures for screening foreign visitors have been tightened. The Office of Counter- intelligence, which was buried within the agency's bureaucracy, has also been raised in status, with Curran reporting direct to Bill Richardson, the energy secretary.

One question now arising is how many laboratory scientists, apart from Lee, ought to be dismissed for lax security practices, such as copying classified e-mails or failing to fully report conversations with foreigners.

Another is whether the Lee incident will lead to the suspension of visits of scientists from sensitive countries, such as China. Los Alamos says 100 Chinese nationals worked at the lab last year and 278 others paid visits.

Richardson has expressed concern about the political reaction to the incident. "I'm concerned Congress is going to over-react. You don't eliminate the foreign visitors programme because it is essential." WilLepkowski

\section{Trade unions campaign for lifelong learning}

[LONDON] Britain's largest science trade unions have called on scientists and employers to pay closer attention to continuing professional development — or lifelong learning - to ensure that scientists remain at the forefront of their profession.

The unions unveiled a 14-point charter on training and development for scientists at a conference in London last week. The initiative was endorsed by the Association of University Teachers, the Institute of Professionals, Managers and Specialists (IPMS), the Manufacturing Science Finance union, and the National Association of Teachers in Further and Higher Education.

The charter calls on employers to set aside at least 2 per cent of their budgets for training and development of scientific staff. It says that scientists should be allowed to take at least 10 days off each year for training and development. And it says that employers should publish performance indicators on their training schemes in their annual reports.

"Those working in universities would need far more than this to keep up with relevant literature and attend conferences. But, all too often, teaching pressures squeeze out time for professional development," says the charter.

Baroness Margaret Sharp, of the Science Policy Research Unit at the University of Sussex, commented: “Most of my staff are working 60 to 70 hours per week [trying to meet] targets for teaching quality and the research assessment exercise. They are too exhausted to train. There just isn't enough time."

The conference heard that Britain's army

^๑) 1999 Macmillan Magazines Ltd of contract researchers, technical staff, and scientists from minority communities were often most in need - but also most likely to miss out on - professional training and development.

In the case of scientists, this is partly because of lack of opportunities, and partly through ignorance of the facilities available, the conference was told. Technical and support staff, on the other hand, miss out on training and development because of a lack of motivation, according to Sue Ferns, a research officer at the IPMS.

Ferns added that scientists often benefit from training in areas outside their scientific expertise, for example in administration or finance, which helps if they need to switch careers. The IPMS has established training partnerships with employers. One scheme enables staff to take a Master of Business Administration degree in technology management from the Open University.

One speaker said that employers are reluctant to fund training for contract staff because they "see themselves as consumers of trained staff, not trainers of people".

Other speakers told the conference that employers are sometimes afraid to invest in people because of a fear of losing their investment if a trained employee leaves the company.

But Sir Geoffrey Allen, chairman of the Science, Technology and Mathematics Council, and a former head of research at the Unilever company, said many large companies expect newly trained, but long-serving, staff to move on. It is an opportunity for the companies to refresh employee teams, he said.

Ehsan Masood 